$\underline{\text { Article }}$

\title{
Determination of Pentachlorophenol in Drinking Water
}

\author{
I.F. Gaspar, L. Polese*, E.V. Minelli, M.L. Ribeiro, and E.F.G. Jardim \\ Departamento de Química Orgânica, Instituto de Química, UNESP, C.P. 355, \\ 14801-970 Araraquara - SP, Brazil
}

Received: September 19, 1996

\begin{abstract}
Este trabalho relata um método envolvendo derivação in situ e extração para determinação de resíduos de PCP em amostras de água. O derivado acetilado de PCP é analisado por cromatografia a gás com detector por captura de elétrons. O limite de detecção do método é de $1 \mu \mathrm{g} / \mathrm{L}$ e sua eficiência é demonstrada pelos valores médios de recuperação (78-108\%) estudados em três níveis de fortificação (2; 10 e $20 \mu \mathrm{g} / \mathrm{L})$.

In this study, an in situ derivatization and extraction method for the determination of pentachlorophenol (PCP) has been applied successfully in the analysis of water samples. The PCP derivative analysis was performed by gas-liquid chromatography with electron capture detection. The limit of detection of the method is $1 \mu \mathrm{g} / \mathrm{L}$ and recoveries averaged $78-108 \%$ for PCP acetate at levels of 2 , 10 and $20 \mu \mathrm{g} / \mathrm{L}$.
\end{abstract}

Keywords: pentachlorophenol, water, gas chromatography, in-situ derivatization

\section{Introduction}

Pentachlorophenol (PCP), a fungicide and insecticide used in wood treatment, agriculture, paper production, and the leather industry, has become a serious environmental concern because of its toxicity to fish and mammals. Several methods have been described to determine PCP by using various analytical techniques ${ }^{1-4}$. Among these techniques, gas liquid chromatography with higher sensivity of the electron capture detector (ECD) allows the PCP determination at very low concentration levels ${ }^{4-5}$,but requires a derivatization step before GC analysis.

Many studies have been reported for derivatization of PCP in water, including acetylation with acetic anhydride leading to pentachlorophenyl acetate ${ }^{6}$ or preparation of the pentachlorophenylmethyl ether derivative with diazomethane $^{7}$. Although the derivatization methods require special pre-chromatographic treatment, the analysis of underivatized phenols by high resolution gas chromatography (HRGC) also has disadvantages. Thus, the derivatization of phenols prior to chromatography is often recommended $^{8}$. The analyses of PCP in water are done using two approaches. One involves the extraction of PCP from samples by solvents before the derivatization, while the other involves the direct derivatization of PCP in aqueous solu- tion (in situ derivatization). The advantages of the in situ derivatization eliminate the deficiencies of incomplete recovery of free PCP from water samples by solvent extraction $^{6}$ and permit derivatization and extraction in a single step. This paper describes a modification of the method proposed by Lee et al. ${ }^{6}$, and involves: in situ acetylation of PCP with acetic anhydride in the presence of potassium carbonate, plus extraction by hexane, and analysis of the extract using gas-liquid chromatography with electron capture detection. The method was used to determine PCP in drinking water samples from different cities of the State of São Paulo, Brazil.

\section{Experimental}

\section{Apparatus and reagents}

A Varian 3300 gas chromatograph equipped with a glass column ( $2 \mathrm{~m} \times 2 \mathrm{~mm}$ id.) packed with $3 \%$ OV 210 on 80-100 mesh Chromosorb WHP, and a constant current ${ }^{63} \mathrm{Ni}$ electron capture detector (ECD) was used for qualitative and quantitative analyses. The signal from the ECD was monitored with a Varian 4290 Integrator. Operating conditions were as follows: injector temperature, $210^{\circ} \mathrm{C}$; column oven temperature, $180{ }^{\circ} \mathrm{C}$; detector temperature, $300{ }^{\circ} \mathrm{C}$; and carrier gas $\left(\mathrm{N}_{2}\right)$ at $30 \mathrm{~mL} / \mathrm{min}$. 
All solvents used were of pesticide grade quality (Carlo Erba): n-hexane, and acetone. Acetic anhydride, anhydrous sodium sulfate and potassium carbonate were of analytical reagent grade (Merck). The PCP standard (99.73\%) was obtained from the Environmental Protection Agency (Triangle Park, NC). Water, deionized and purified with a Milli-Q® apparatus (Millipore), was used in the recovery study.

\section{Method}

The analyses were performed as shown in Fig. 1. In recovery experiments, water samples were fortified with $5.0 \mathrm{~mL}$ of PCP solutions in acetone at appropriate concentrations $(2,10$ and $20 \mu \mathrm{g} / \mathrm{L})$ and were allowed to equilibrate for $30 \mathrm{~min}$ in an ultrasonic bath before analysis. The percentage recoveries were calculated by comparing the average chromatographic peak areas of the fortified sample, unfortified sample and derivatized standard solution. The scheme of the standard solution derivatization is presented in Fig. 2.

Water samples (two liters) were collected in glass bottles, from five cities in the State of São Paulo, and were analyzed in duplicate.

\section{Results and Discussion}

The establishment of the experimental conditions was based on a method described by Lee et al. ${ }^{6}$ for the analyses of chlorophenols in natural water by in situ acetylation. In this method, phenols were acetylated in the presence of $\mathrm{KHCO}_{3}$ and the resulting acetates were extracted by petroleum ether followed by silica gel column chromatography cleanup. In the present study preliminary investigations

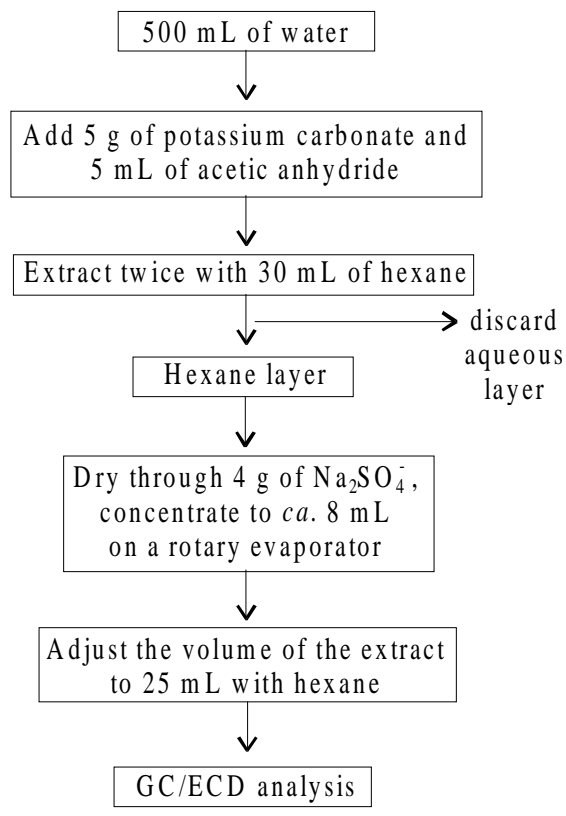

Figure 1. Scheme of experimental procedure. were performed by using $\mathrm{Na}_{2} \mathrm{CO}_{3}, \mathrm{KHCO}_{3}, \mathrm{~K}_{2} \mathrm{CO}_{3}$ and n-hexane in the acetylation and extraction of PCP acetate. The highest efficiency was achieved by using $\mathrm{K}_{2} \mathrm{CO}_{3}$, thus, starting from optimized conditions, a recovery study with fortified samples at three concentration levels was carried out. Recovery data (Table 1) ranged from 78 to $108 \%$ and the detection limit, calculated as described by Thier and Zeumer ${ }^{9}$, was $1 \mu \mathrm{g} / \mathrm{L}$. Although these values are in good agreement with the results obtained by Lee et al. ${ }^{6}$, the described procedure presents certain advantages. It permits a reduction in both time and the amount of solvent required for extraction. Furthermore, gas chromatograms (Fig. 3)

Table 1. Recoveries of pentachlorophenol (PCP) as acetate from water.

\begin{tabular}{lccc}
\hline Analyses & \multicolumn{3}{c}{ Recovery $(\%)$} \\
\cline { 2 - 4 } & $20 \mu \mathrm{g} / \mathrm{L}$ & $10 \mu \mathrm{g} / \mathrm{L}$ & $2 \mu \mathrm{g} / \mathrm{L}$ \\
\hline 1 & 78 & 88 & 90 \\
2 & 82 & 93 & 96 \\
3 & 91 & 94 & 79 \\
4 & 84 & 81 & 85 \\
5 & 108 & 106 & 87 \\
\hline Mean & 89 & 92 & 87 \\
\hline Standard & 11.8 & 9.2 & 6.3 \\
deviation & & & \\
\hline
\end{tabular}

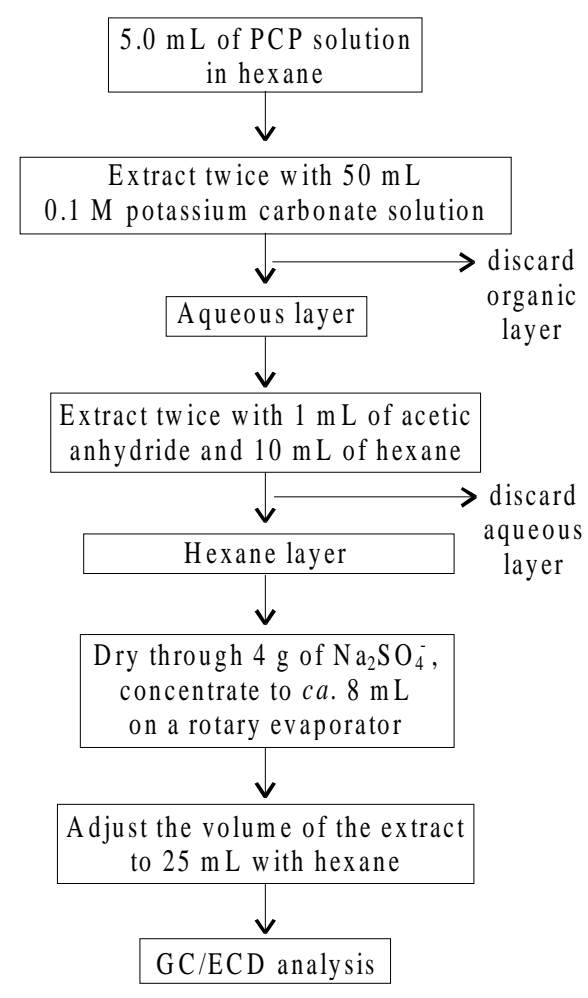

Figure 2. Scheme of standard solution derivatization. 


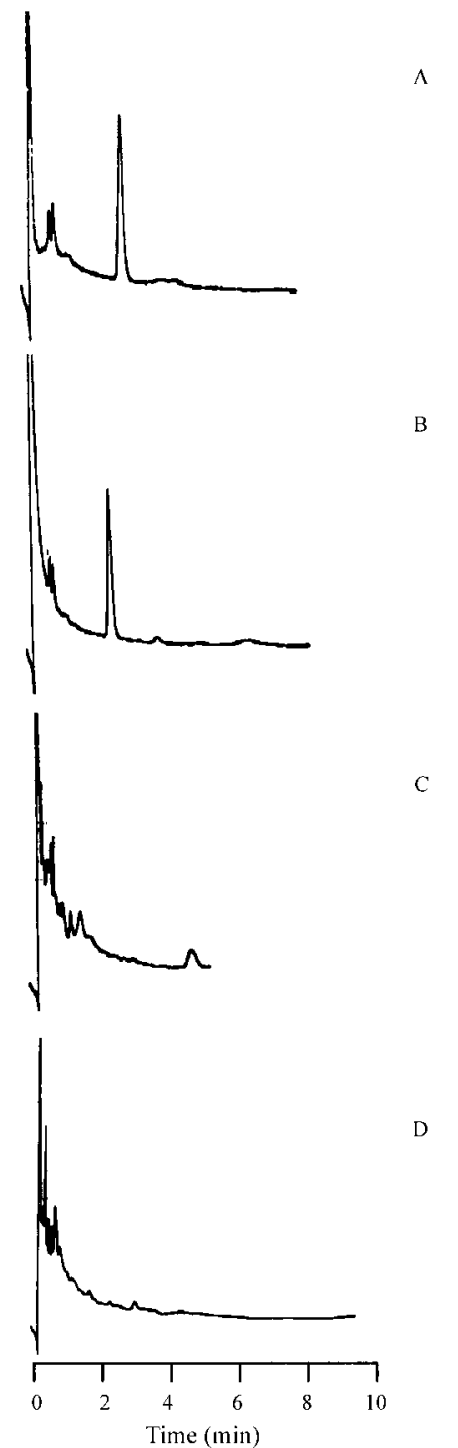

Figure 3. Gas chromatograms of A derivatized standard solution; B fortified water sample $(10 \mu \mathrm{g} / \mathrm{L})$; C unfortified water sample; D well water sample. show that no additional cleanup step was needed after the extraction procedure. For determining the recovery values, standard solutions of PCP were derivatized parallel to the samples. This procedure has been discussed by several authors $^{6,10-11}$.

Governmental norms were established for controlling pollution of water by chemicals in Brazil ${ }^{12}$ and the maximum residue limit recommended for PCP in drinking water is $10 \mu \mathrm{g} / \mathrm{L}$. This value is the same as that recommended by the World Health Organization ${ }^{13}$. In order to assess PCP municipal drinking water contamination, nine samples were collected from cities of the most developed industrial state of Brazil. Some geographical data of the cities selected are presented in Table 2. The cities were selected depending on their proximity to leather, chemical, or paper industries.

All samples contained residues of PCP, but at lower levels than the detection limit of the method. On the basis of the results obtained in this study, it was concluded that PCP does not represent an expressive environmental contaminant to these cities. However, further monitoring studies are necessary to evaluate PCP pollution in the Brazilian environment.

\section{References}

1. Carr, R.S.; Thomas, P.; Neff, J.M. Bull. Environ. Contam. Toxicol. 1982, 28, 477.

2. McMurtrey, K.D.; Holcomb, A.E.; Ekwenchi, A.U.; Fawcett, N.C. J. Liq. Chromatogr. 1984, 7, 953.

3. Reig, F.B.; Falcó, P.C.; Andrés, J.V. J. Liq. Chromatogr. 1995, 18, 2229.

4. Besner, A.; Gilbert, R.; Tétreault, P.; Lépine, L.; Archambault, J.F. Anal. Chem. 1995, 67, 442.

5. Abrahamsson, K.; Ekdahl, A. J. Chromatogr. 1993, 643, 239.

6. Lee, H.B.; Weng, L.D.; Chau, A.S.Y. J. Assoc. Off. Anal. Chem. 1984, 67, 789.

Table 2. Geographical data of the selected cities and collected samples.

\begin{tabular}{|c|c|c|c|c|}
\hline City & Localization & Population & Economic activities & Samples \\
\hline Araraquara & $\begin{array}{l}\mathrm{S} 21^{\circ} 47^{\prime} \\
\mathrm{W} 48^{\circ} 10^{\prime}\end{array}$ & 172,786 & $\begin{array}{l}\text { agriculture } \\
\text { and industry }\end{array}$ & $\begin{array}{c}\text { tap water } \\
\text { ground water }\end{array}$ \\
\hline Batatais & $\begin{array}{l}\mathrm{S} 20^{\circ} 54^{\prime} \\
\mathrm{W} 47^{\circ} 35^{\prime}\end{array}$ & 46,313 & $\begin{array}{c}\text { agriculture } \\
\text { and cattle breeding }\end{array}$ & tap water \\
\hline Franca & $\begin{array}{l}\mathrm{S} 20^{\circ} 32^{\prime}, \\
\mathrm{W} 47^{\circ} 24^{\prime}\end{array}$ & 253,876 & $\begin{array}{c}\text { agriculture } \\
\text { and leather industry }\end{array}$ & $\begin{array}{l}\text { tap water } \\
\text { ground water }\end{array}$ \\
\hline Rio Claro & $\begin{array}{l}\mathrm{S} 22^{\circ} 25^{\prime} \\
\mathrm{W} 47^{\circ} 33^{\prime}\end{array}$ & 145,168 & $\begin{array}{l}\text { agriculture } \\
\text { and industry }\end{array}$ & $\begin{array}{l}\text { tap water } \\
\text { well water }\end{array}$ \\
\hline Sorocaba & $\begin{array}{l}\mathrm{S} 23^{\circ} 30^{\prime}, \\
\mathrm{W} 47^{\circ} 28^{\prime}\end{array}$ & 405,979 & industry & $\begin{array}{c}\text { tap water } \\
\text { ground water }\end{array}$ \\
\hline
\end{tabular}


7. Edgell, K.W.; Erb, E.J.; Wesselman, R.J.; Longbottom, J.E. J. Assoc. Off. Anal. Chem. Int. 1993, 76, 1098

8. Mußmann, P.; Levsen, K.; Radeck, W. Fresenius J. Anal. Chem. 1994, 348, 654.

9. Gorbach, S.G.; Bos, U.; Thier, H.P.; Frehse, H.; Weinmann, W.D. In Manual of Pesticides Residue Analysis; Thier, H.P.; Zeumer, H., Eds.; VCH; New York, 1987, Vol. 1, p. 37.
10. Janda, V.; Van Langenhove, H. J. Chromatogr. 1989, $472,327$.

11. Kolb, M.; Böhm, H.B.; Bahadir, M. Fresenius J. Anal. Chem. 1995, 351, 286.

12. Brasil, Diário Oficial da União / Ministério da Saúde, Portaria $\mathrm{n}^{\circ} 36,1990$.

13. World Health Organization (WHO), Guidelines for Drinking Water Quality, Recommendations, 1984.

FAPESP helped in meeting the publication costs of this article 